\title{
DEVELOPMENT OF TRAM TRAFFIC IN THE CITY OF OSIJEK
}

\section{Sanja Dimter}

Professional paper / Stručni rad Josip Juraj Strossmayer University of Osijek, Faculty of Civil Engineering Osijek, Associate Professor Corresponding author: sdimter@gfos.hr

\section{Zoran Tanasić}

Gradski prijevoz putnika d.o.o.Osijek, CE.

\section{Martina Zagvozda}

Josip Juraj Strossmayer University of Osijek, Faculty of Civil Engineering Osijek, mag.ing.aedif.

\section{Filip Ruška}

Zavod za urbanizam i izgradnju d.d. Osijek, mag.ing.aedif.

\begin{abstract}
The need for the introduction of trams in Osijek in the late $19^{\text {th }}$ century was largely due to the poor connectivity between the areas of the city and the growing development of the city. Tram transport was an extremely important step in connecting and modernizing the city and a key step in the integration of the still unconnected areas of the city, a role it has played throughout history. From its beginnings, the residents of Osijek have been intricately connected to the tram, which has had a role in the modernization of the city and is today regarded as a symbol of the city. As a means of public transport, in Croatia, the tram is now used only in Zagreb and Osijek. Today, many cities around the world have reintroduced trams as a public transport system, and Osijek is one of the few "small" cities that can boast of its continuous existence and expansion. This paper describes the development and current state of tram traffic in Osijek as a contribution to the celebrations of the anniversary of the introduction of the electric tram in the city.
\end{abstract}

Keywords: tram, tramway, tram tracks, city of Osijek

\section{RAZVITAK TRAMVAJSKOG PROMETA GRADA OSIJEKA}

Sažetak: Potreba za uvođenjem tramvaja u Osijeku krajem 19. stoljeća bila je velika zbog slabe povezanosti dijelova grada i njegove sve veće razvijenosti. Pokretanje tramvajskog prijevoza bio je iznimno važan korak u povezivanju i modernizaciji grada i ključni korak u integriranju tada još nepovezanih gradskih cjelina, a tu ulogu zadržao je kroz cijelu povijest. Od samih početaka, stanovnici Osijeka su posebno vezani za tramvaj koji je imao važnu ulogu i u modernizaciji grada, a danas je tramvaj svojevrstan simbol grada. Tramvaj u javnom prometu u Hrvatskoj danas se koristi jedino u Zagrebu i Osijeku. Mnogi gradovi svijeta danas ponovo uvode tramvaje u sustav javnog prijevoza, a Osijek je među rijetkim "malim" gradovima koji se mogu pohvaliti njegovim neprekinutim postojanjem i proširenjem. U ovome radu opisan je razvoj i postojeće stanje tramvajskog prometa u Osijeku, kao prilog obilježavanju obljetnice uvođenja električnog tramvaja u Osijeku.

Ključne riječi: tramvaj, tramvajska pruga, kolosijek, Osijek

Dimter, S, Tanasić, Z, Zagvozda, M, Ruška, F 


\section{INTRODUCTION}

The inception of tramway transport in Osijek was an extremely important step in the connection and modernization of the city, and a key step in the integration of the city's still unconnected areas. This is a role that the tram has kept throughout its history, and today Osijek and Zagreb are the only Croatian cities where it is used as a means of public transport. Although buses are also used for public transport, the citizens of Osijek have, from the very beginnings of public transport, favored the tram because buses were considered noisy and uncomfortable when introduced and tram transport was cheaper. The tram has also directly influenced other events in the city. For example, the construction of a tram was one of the reasons for the decision to build a power plant and electrify the city, with important implications for the entire city.

Owing to the significantly lower costs of building and maintaining its infrastructure, as well as its low environmental impact and high passenger comfort, the tram presents a good quality and cost-effective solution to urban traffic compared with other means of public transport. Today, many cities around the world have reintroduced trams to the public transport system. Some big cities, such as Amsterdam, Barcelona, Berlin, Budapest, Melbourne, Munich, Prague and Vienna, have a long continuous history with the tram. Smaller cities in the vicinity of Osijek, such as Novi Sad, Pecs, and Subotica, also introduced tramway transport around the turn of the $20^{\text {th }}$ century. Most of these cities have since abandoned this form of transport, but in some there are future plans of its reintroduction (e.g. Novi Sad, Pecs). It was also abandoned in Croatian coastal cities, such as Rijeka, Dubrovnik, Pula, and Opatija, where it was once used. Osijek is one of the few "small" cities that can boast its continuous existence and expansion. The importance of tram traffic is also evidenced by the number of passengers that it serves: every year, trams carry $7,200,000$ passengers in Osijek, who constitute $70 \%$ of all passengers using the city's public transportation system.

\section{HISTORICAL DEVELOPMENT OF TRAM TRAFFIC IN CITY OF OSIJEK}

On September 10, 1884, Osijek was the first city in Croatia and one of the first cities in Central Europe to receive the most up-to-date urban transport, a horse tram, at a time when the city had 18,000 residents. In the previous year, on July 14, 1883, the City Council had assigned the exclusive right for the building of the horse railways to the Osijek Joint Stock Company for Horse Railways [1]. These were completed in less than a year, and comprised $4.5 \mathrm{~km}$ of single tracks with passing loops at the busiest terminus stations.
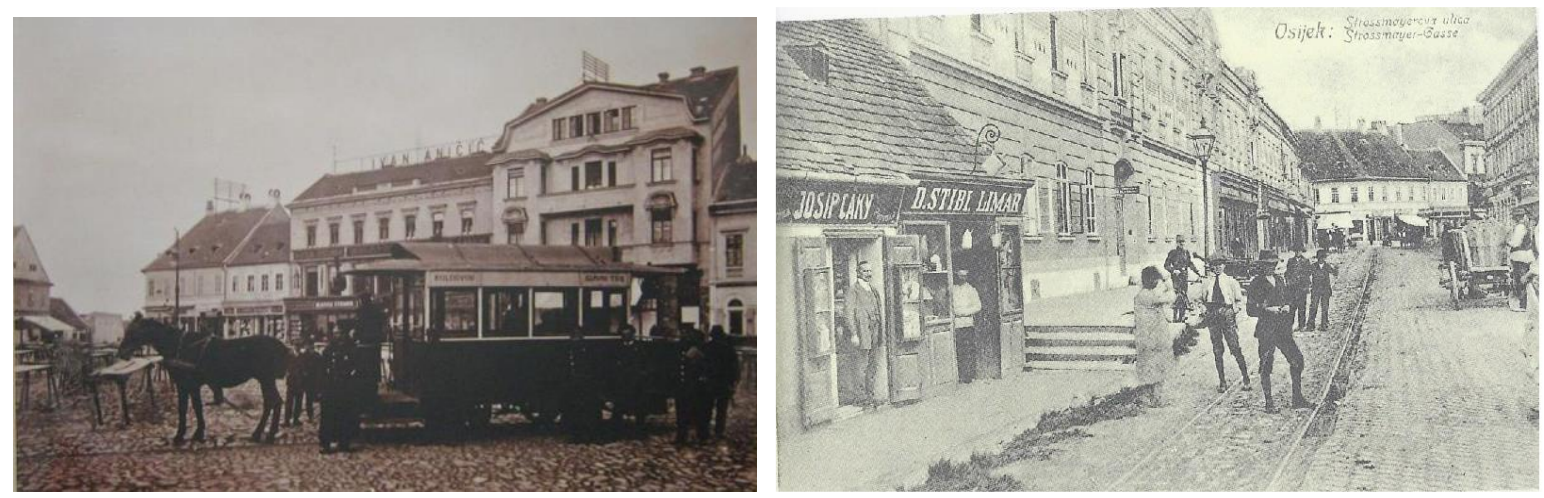

Figure 1 Left: Market and horse tram on the main square in Osijek [2], and Right: View of tram tracks on Duga (Strossmayerova) Street [3]

Dimter, S, Tanasić, Z, Zagvozda, M, Ruška, F 
Osijek was then $10 \mathrm{~km}$ long from east to west, and the railroad was built on Duga (Strossmayer) Street near the Church of St. Rok, through Khuen Hedervary Square (today's Square A. Starčević) to Donji Grad Main Square. The Company's administration building was located along the former Chavrakova Street (today's Europska Avenija), the rails of the tram went along the driveway to the River Drava (today's V. Hengl Promenade), and stables for horses were located behind the administration building, parallel to the River Drava. Shortly after the construction of the basic tram route from east to west, so called lateral track lines were built to the railway station and Gradski Vrt in Novi Grad.

The constructed railway was of a narrow-gauge type, with an inner space between the rails of $71 \mathrm{~cm}$. Between the rails and on both outer sides of the tracks, paved stone blocks were placed in widths of $50 \mathrm{~cm}$ for the passage of the horses and the tram duty guards (Figure 1). The tram stops at the termini of the line and at the two city squares were covered and enclosed, and were constructed of wood [1].

The closed tramcars were produced in Graz, and had a length of $5 \mathrm{~m}$, a width of $1.8 \mathrm{~m}$ and a height of $2.5 \mathrm{~m}$. They had 16 seats, and were mostly pulled by two horses, although sometimes one horse, for a maximum of two hours, after which the horses were replaced with rested horses. The horses had bells on their head, and their ringing signaled the approach of the trams to people standing by at the stops. The horse-drawn tramcar moved at a speed of $7.5 \mathrm{~km} / \mathrm{h}$. A coachman and conductor were on duty in each tramcar, along with a tram guard who took care of passenger safety. All of the officials were dressed in uniforms, and all of the passengers in the trams had to abide by strict rules [4].

In addition to 15 passenger tramcars travelling on the railroad, at certain times there were up to eight freight wagons and two postal wagons. This cargo tram traffic was unique to Osijek, and permitted the transport of goods from the railway station to the former city port by cargo tram carriages.

Osijek's horse driven tram connected the city for 42 years, but over time it became too slow for the new rush of the times. With the new era, there was an increasing need for modernization and electrification of both the city and tram traffic. Although plans for electrification of the tram system were finalized in 1914, its realization had to be delayed owing to the start of World War I. After the end of the war, the city accepted the offer of an American company, Charles McDaniel, with which it contracted to carry out a projects for the building of a power plant (which was named Munjara) as well as electrification of the city and tram system.
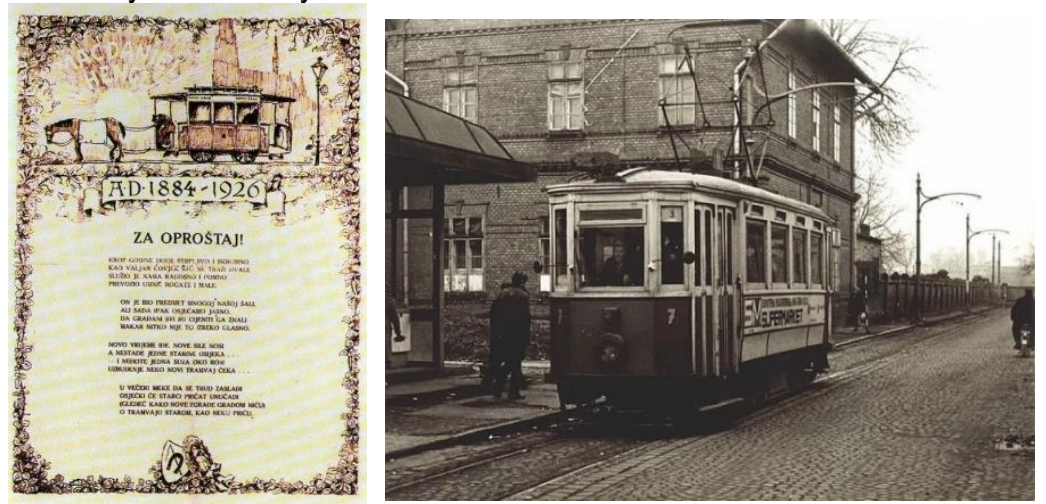

Figure 2 Left: Farewell poem to horse tram [5], and Right: the first electric tram

After the electrification of the city, the horse tram was superseded by the electric tram. The route on which the tram travelled also changed: now it no longer entered the Tvrđa, and the current tram route from the Gornji to the Donji Grad was set. The electric tram commenced operations on December 12, 1926. The tramway was over $9 \mathrm{~km}$ long, including Remiza Depot, tram stops, and associated facilities, and the width of the track was set at $1 \mathrm{~m}$. Traffic was transported by six vehicles on the Gornii Grad-Donji Grad line, from the intersection of Strossmayerova and Kanižlićeva Streets to Zeleno Polje, and on the lateral line to Gornjodravska Railway Station. It was planned to introduce new city

Dimter, S, Tanasić, Z, Zagvozda, M, Ruška, F 
lines going to Novi Grad, but owing to the construction challenges of crossing the railroad tracks in Trpimirova Street, this was delayed [6]. The first electric trams in Osijek were produced by the Tatra Company in Czechoslovakia (Figure 2).

During World War II, tram traffic in the city became irregular, especially because of the lack of electricity, but also because of a lack of skilled labor. Upon the ending of the war, tramway traffic began to normalize after a while.

The next renovation of the tracks took place in the 1960s and 70s, when the tram line was extended and expanded to Višnjevac (comprising 2,481 m of tracks from the existing U-turn (terminus) on Kanižlićeva Street to a new U-turn called Višnjevac).

There were extensive plans for the further development of the tram network in Osijek in the 1970s, because the tram, despite the large number of bus lines in the city, comprised the backbone of the public transport system. According to the Traffic Plan of the Osijek 2000 Master Plan [7] made in 1975, the extension of the tram network was planned for the following directions: east, to the industrial zone and Nemetin Port; west to the Josipovac; south on Vinkovačka Street to the Novo Groblje, and on Svačićeva Street (formerly F.Milića) to Tenja (Figure 3).The Master Plan also shows the planned construction of a new tram network in the northern areas across the Drava, with expansion up to Darda.

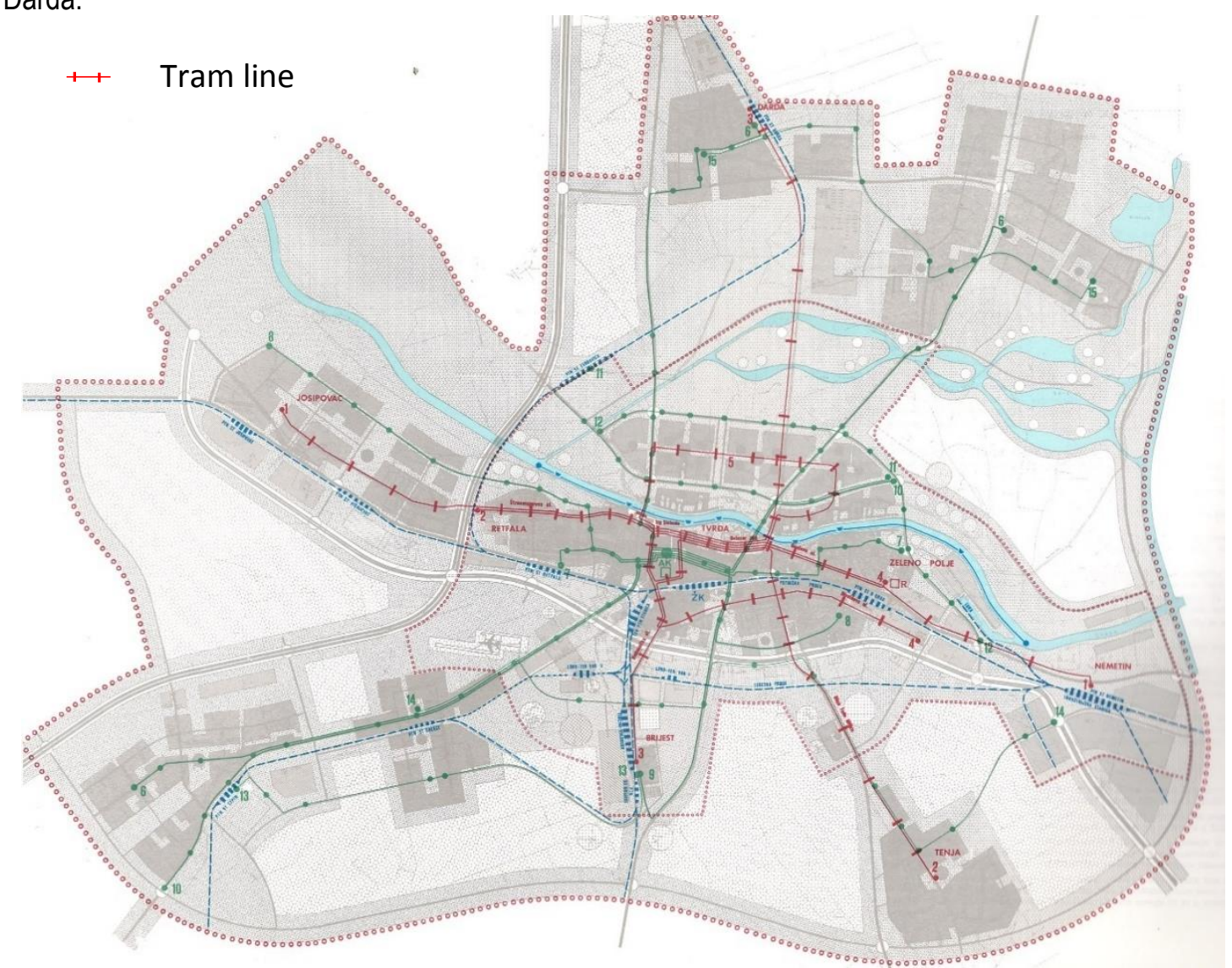

Figure 3 Excerpt from Traffic Plan of Osijek 2000 Master Plan [7]

The next extension of the tramline was in 2006 from Vinkovačka Street to Mačkamama and in 2009 to Bikara. In 2014 a line to the center of Višnjevac was built.

Dimter, S, Tanasić, Z, Zagvozda, M, Ruška, F 


\section{TRAM INFRASTRUCTURE TODAY}

Today, the tram lines in the city of Osijek are $29,879 \mathrm{~m}$ long, comprising $29,229 \mathrm{~m}$ of track in the city, $550 \mathrm{~m}$ of track in workshops, and $100 \mathrm{~m}$ of blind track for the old trams. The tramways are $1 \mathrm{~m}$ wide, the same as when operations commenced in 1926. The network in the city is divided into two lines, one that connects the eastern and western parts of the city longitudinally (Line 1), and a shorter line in the transverse direction (Line 2) (Figure 4).

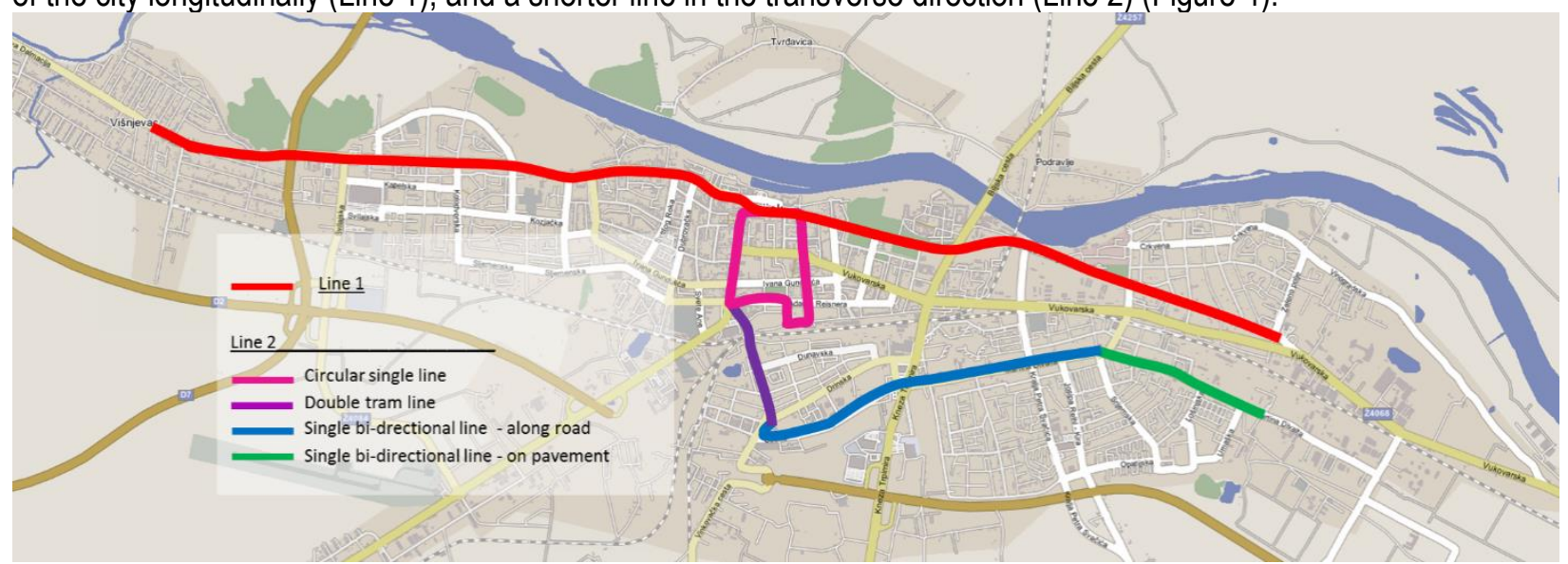

Figure 4 Tram lines in city of Osijek in 2016

Line 1 extends in an east-west direction from the tram U-turn in Zeleno Polje to the U-turn in the middle of the suburb of Višnjevac. In addition to the termini having U-turns, there are two extra U-turns, one at the intersection of Strossmayerova and Kanižlićeva Streets, and one on the border of the city of Osijek and the suburb of Višnjevac. These are witnessing the phase building and expansions of tramlines. Line 1 consists of a double-track railway line, mainly running along the roadway. A small part of the railway is designated as part of the roadway, with one section on the stretch of the Europska Avenija from Kuhačeva Street to the beginning of the pedestrian zone in Kapucinska Street, and another section after Ante Starcevic Square, on Strossmayerova Street to the intersection with Rok Street. On Line 1 there are a total of 25 tram stops at which the trams stop a total of 148 times each day.
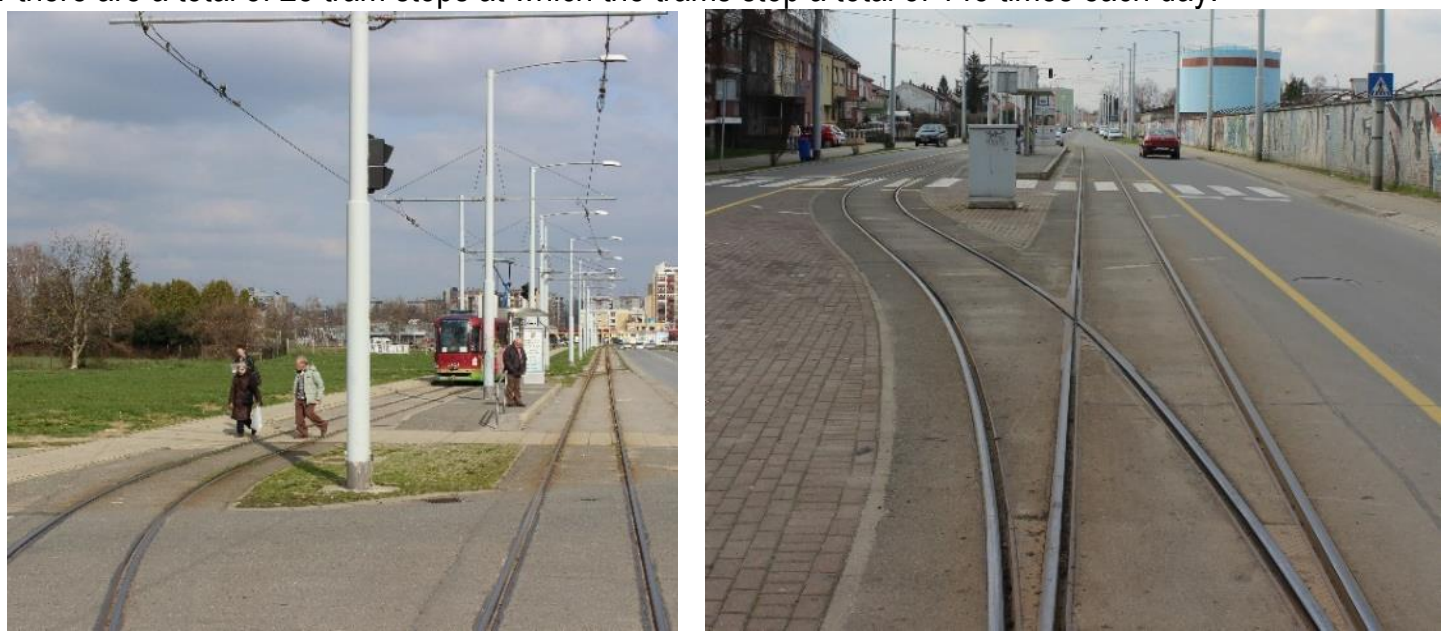

Figure 5 Passing loops with tram stops on Line 2

Dimter, S, Tanasić, Z, Zagvozda, M, Ruška, F 
Line 2 consists of three distinct parts: the first two parts are a circular single tram line and a double tram line that transversely connect the southern parts of the city with Ante Starcevic Square, and the third is a single bi-directional tramline running longitudinally through the southern city districts. In addition to standard signalized and unsignalized level intersections, this tramway line intersects three roundabouts. The circular single tram line, in which the tram runs mainly on the pavement with road transport, connects Ante Starcevic Square with bus and railway stations. From Đakovština roundabout to Mačkamama roundabout, Line 2 is a double tramway line running along side road transport on the pavement of Vinkovačka Street. It then continues as a single bi-directional tram line to the U-turn at the intersection of Divaltova and Velebitska Streets. On the first stretch, the railway runs along the northern edge of the road separately from the pavement to the intersection with Hutlerova Street, after which it continues along the middle of the roadway on Divaltova Street to the U-turn. To enable two-way traffic on the single tram line, there are six passing loops within incorporated tram stops (Figure 5). In total, on Line 2 there are 15 tram stops at which the trams stop a total of 78 times a day. Special features of this single bi-directional tram line and safety measures for all road users are described in the study by Zagvozda et al. [8]. The particular two-way traffic being conducted on this line results in a higher number of traffic accidents than that occurring on the remainder of the tram network, especially because road vehicles do not expect the emergence of a tram in a neighboring traffic lane and travelling in a direction that is opposite to the flow of road vehicles.

\subsection{Tramway structures}

Owing to the different periods of tramway construction, the different spaces through which the tracks are passing, and the positions of the tracks in the cross-sections of city streets, several different types of track structures exist. These can generally be divided into those on crushed stone (ballast) base and those on a concrete base. The tracks on a ballast base are free-standing tramways with grooved rails connected with laces, sealed with stone aggregate, and laid in a total length of $3,886 \mathrm{~m}$ (Figure 6).

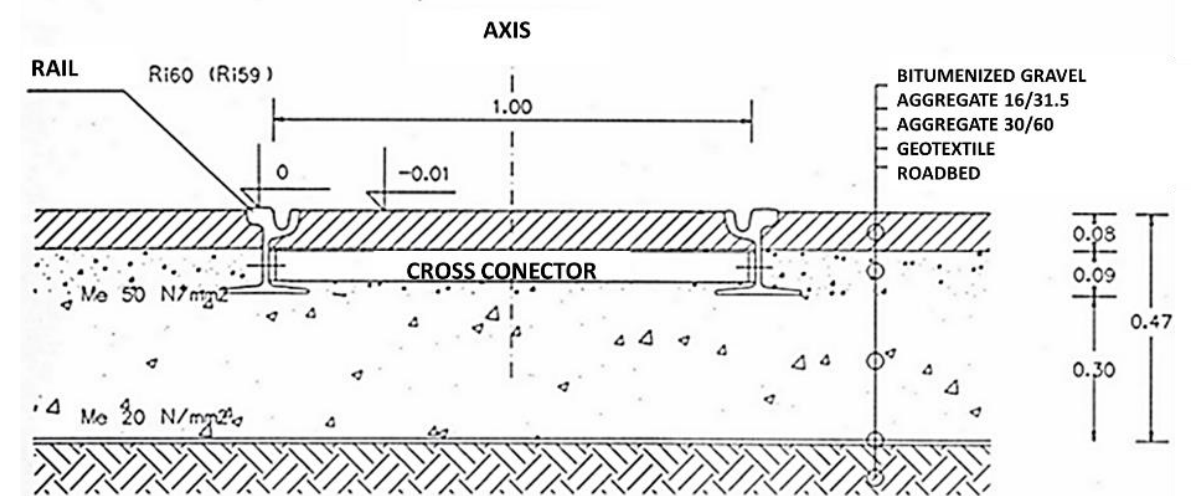

Figure 6 Examples of track structures on ballast base [9]

The tracks laid on a concrete base have a total length of $25,343 \mathrm{~m}$. As with the ballast base, grooved rails are applied, but these are attached with anchor bolts to the reinforced concrete (RC) slab or I-beam, depending on the type of upper structure used (ZG-2, DEPP, inverse DEPP). The cross-section of the tramway is dependent on the position relative to the road; sections guided along the roadway are usually in unbound aggregate layers with granulation from 16 to $31.5 \mathrm{~mm}$, while sections that comprise part of the pavement are filled with a layer of concrete and asphalt (Figure 7). In the areas with squares and pedestrian zones, the infill consists of an RC slab made by the Lučko Company.

Dimter, S, Tanasić, Z, Zagvozda, M, Ruška, F 


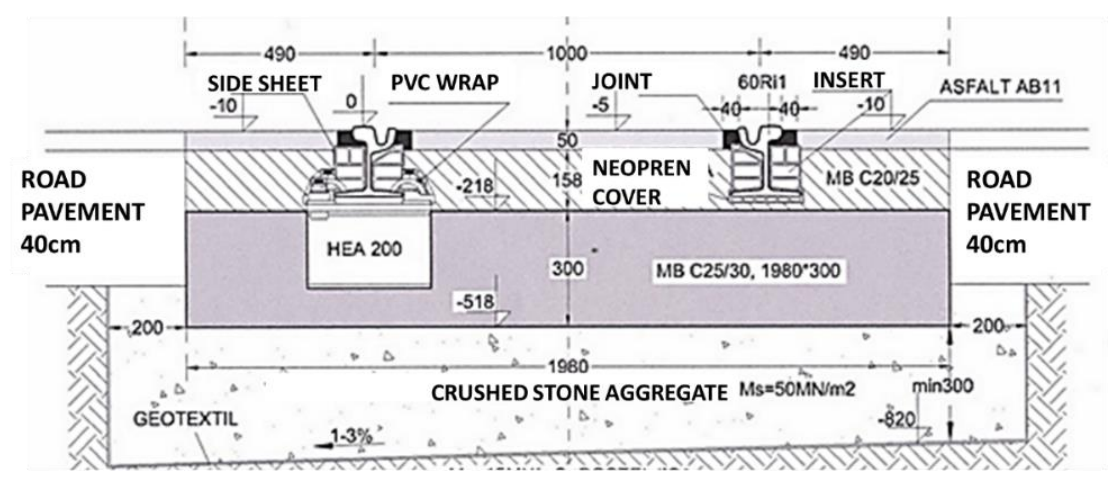

Figure 7 Examples of track structures on concrete base [9]

\subsection{Shunts and crossings}

On both lines of tram tracks in Osijek, there are a total of 41 shunts and 5 crossings (Figure 8). Four of the shunts are operated with an automatic switching (electromagnetic) mechanism. Two of these were built during the reconstruction of Ante Starcevic Square in 2004, while the other two were built in 2006 at Đakovština and Mačkamama roundabouts. There are 14 semi-automatic shunts (hydraulic), and all are found on the single bi-directional tram line built in 2009 on Gacka and Divaltova Streets. The other 23 shunts are mechanical with hand switching. Of these, six are located in front of the depot, seven on exit tracks at the traffic office, six on Line 1 and four on Line 2.

Crossing $\mathrm{K} 1$ is located on Line 1, providing an auxiliary U-turn at the intersection of Strossmayerova and Kanižlićeva Streets, while Crossings K2 and K3 are located at the intersections of Lines 1 and 2, at the corner of Europska Avenija and Radiceva Street and at Ante Starcevic Square, respectively. Crossings K4 and K5 were constructed in 2002 where the Line 1 tram tracks intersect with the industrial HŽ railway tracks. [9]

TRAM LINE IN OSIJEK

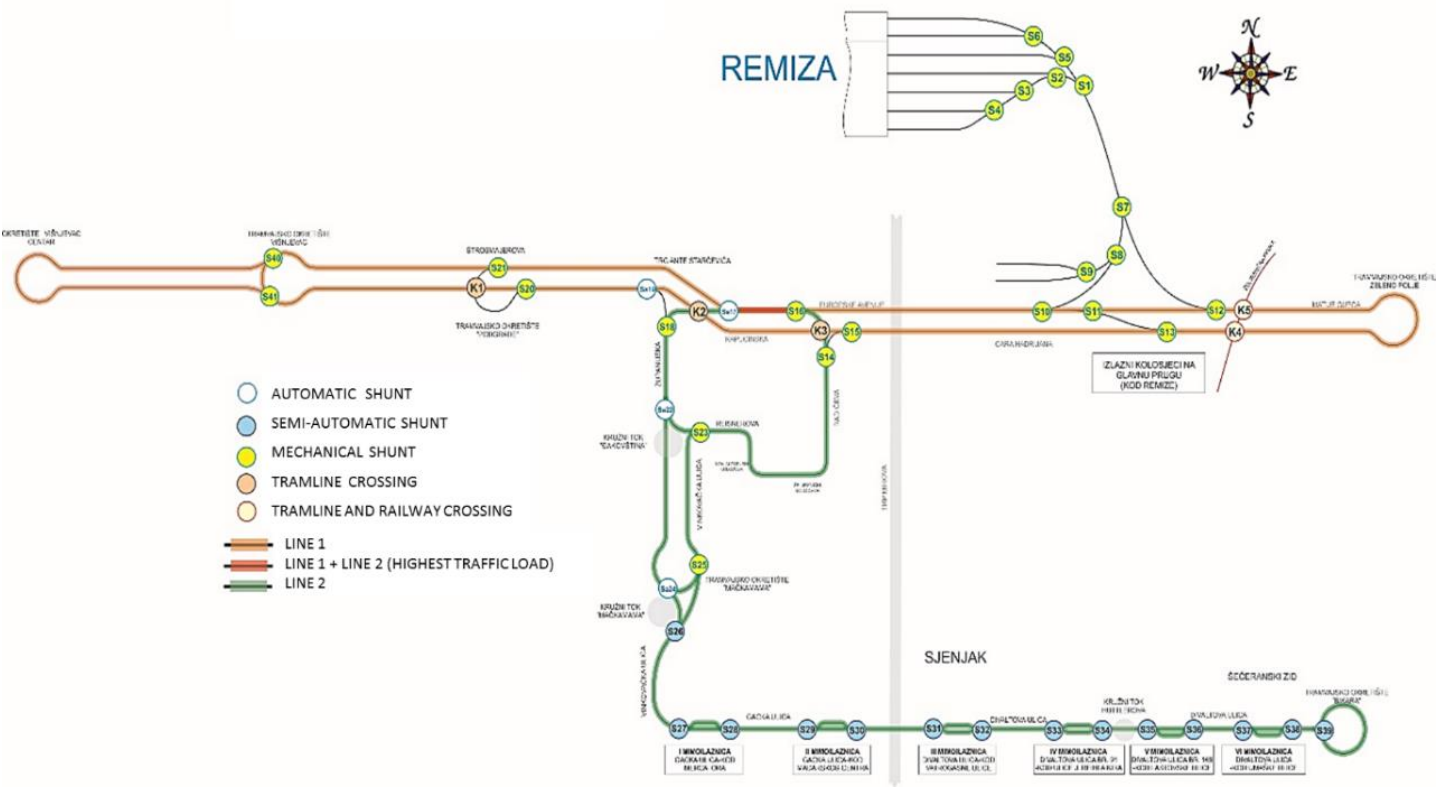

Figure 8 Diagram of shunts and crossings for the tram tracks [9]

Dimter, S, Tanasić, Z, Zagvozda, M, Ruška, F 


\subsection{Cable and contact network}

Electric trams are powered by the electricity network made up of the main line (contact line), rails, and voltage and return cable lines $[9,10]$. The power supply voltage of $660 \mathrm{~V}$ from the contact line is provided through the roof current collector (pantograph), and a current circuit is closed via the rail. In the rectifier stations, the alternating current is first reduced to the required voltage and then converted to direct current. Today, as part of the tram network in Osijek, there are three such rectifier stations: for Gornji Grad in Jägerova Street, for Donji Grad on B.J.Jelacica Square, and for Line 2 near the Divaltova and Svačićeva intersection.

The cable network for the power supply contact network is divided into sections $600-800 \mathrm{~m}$ long, which is powered from the nearest rectifier station. The cables are laid in cable ducts or directly in an earth trench at a depth of $0.8 \mathrm{~m}$, or below the pavement in a casing at a depth of 0.9 to $1.2 \mathrm{~m}$. The contact network consists of driving copper wire and elements on which it is suspended. The suspension components consist of pillars (which are also used for public lighting) or buildings along the tracks.

\subsection{Tram vehicles}

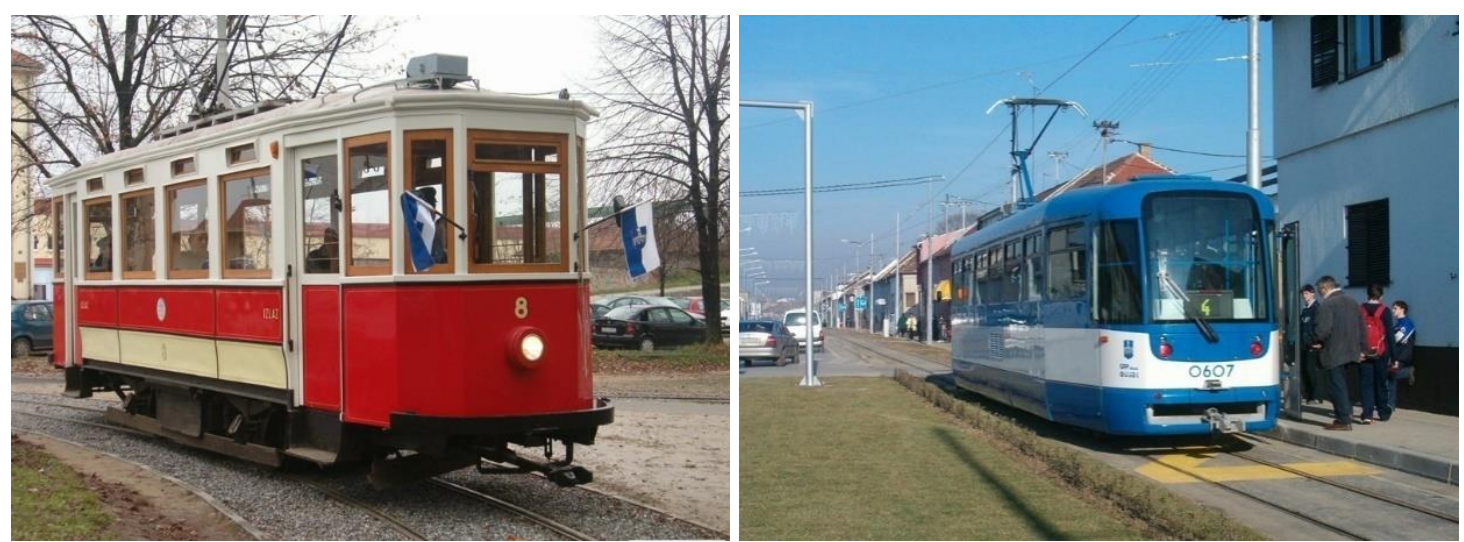

Figure 9 Left: tourist tram, and Right: modern one [11]

The operator for tram traffic in Osijek is City Passenger Transport (Gradski prijevoz putnika - GPP d.o.o). In providing public transport for passengers today, it operates a total of 27 trams (Figure 9). There are three models of trams: 17 vehicles of type T3RPV, made by Škoda in 2006 and 2007; one vehicle of type T3, also made by Škoda in 1981; and nine vehicles of type GT-6, made by Duwag in 1960 and 1971. In addition to trams used for daily transport, occasionally a fourth model of tram runs on the Osijek tracks for tourists. This is the restored Škoda production tram from 1928, formerly known as Tram Number 8.

\section{Interesting facts}

In the streets of Osijek, it is now possible to see four different models of trams, of which the oldest dates from 1928 and is used for tourist rides through the city. It is interesting to note that the first trams to run in 1884 were painted in the color red, allegedly according to the request of Emperor Franz Joseph for the trams to resemble Viennese trams. Today, the trams are painted white and blue, the colors of the city [12]. 


\section{CONCLUSION}

Since its introduction at the end of the 19th century, the tram has become woven into the fabric of everyday life in Osijek, and over time it has obtained the status of a symbol of the city. The tram network has changed over time and has expanded according to the needs of the times and the development of the city. Given its status in the city of Osijek and all the benefits it provides, it is expected that tram transport will continue to develop according to the necessities of public transport.

Future extensions of the tram network should take into consideration the linking of existing longitudinal lines with transverse lines, for which plans have been in place since 1975. In addition to expanding the network of tram lines within the city, the tram should link additional suburbs to the city center.

\section{References}

[1] Živaković-Kerže, Z., 1996: Urbanizacija i promet grada Osijeka na prijelazu stoljeća (1868-1918), Osijek (in Croatian)

[2] Fotografije starog Osijeka, https://rektorat.unios.hr/skup_2015/stari_osijek/stari_osijek159.jpg Accessed 6. November 2016.

[3] Grgurovac, M., 1990: Razglednice starog Osijeka, Osijek (in Croatian)

[4] Osječki tramvaj (1884-1945) http://os-amihanovicaos.skole.hr/tramvaj?only mod instance=52 1010 0\&st3 action=move doc\&st3 id=\# ftn2 Accessed 6. November 2016

[5] Fotografije starog Osijeka, https://rektorat.unios.hr/skup_2015/stari_osijek/stari_osijek095.jpg Accessed 6. November 2016. (in Croatian)

[6] Skupina autora, 1998: Gospodarstvo Osijeka 1196-1996, Osijek (in Croatian)

[7] Urbanistički plan Osijek 2000, Skupština općine Osijek, Urbanistički institut SR Hrvatske, 1975. (in Croatian)

[8] Zagvozda, M., Dimter, S., Ruška, F., 2016.: Route guidance of tram traffic in cities: Particularities of tram traffic in the City of Osijek, 4th International Conference on Road and Rail Infrastructure, Šibenik, 23-25 May 2016. pp. 353-358

[9] Presjek stanja u Tehničkom sektoru GPP-a, Gradski prijevoz putnika d.o.o. Osijek, 2016. (in Croatian)

[10] Legac i suradnici, 2011: Gradske prometnice, Sveučilište u Zagrebu, Fakultet prometnih znanosti, Zagreb (in Croatian)

[11] Gradski prijevoz putnika: Stari tramvaj i Tramvaj T3PVO, http://www.gpp-osijek.com/gallery.php Accessed 6. November 2016. (in Croatian)

[12] Turistička zajednica Osijek: Atrakcije: Tramvaj: http://www.tzosijek.hr/stranica.php?id=58 Accessed 6. November 2016. (in Croatian) 